\title{
Kadar Interleukin-6 Serum pada Karsinoma Payudara Lanjut Lokal dan yang Bermetastasis
}

\author{
Toha Sapari, ${ }^{1}$ Maman Abdurahman, ${ }^{2}$ Anna Tjandrawati ${ }^{3}$ \\ ${ }^{1}$ SMF Bedah Rumah Sakit Umum Daerah Tasikmalaya, ${ }^{2}$ Departemen Patologi Klinik Fakultas \\ Kedokteran Universitas Padjadjaran/Rumah Sakit Dr. Hasan Sadikin Bandung, ${ }^{3}$ Departemen Ilmu \\ Bedah Fakultas Kedokteran Universitas Padjadjaran/Rumah Sakit Dr. Hasan Sadikin Bandung
}

\begin{abstract}
Abstrak
Karsinoma payudara merupakan kanker pada wanita dengan frekuensi tertinggi di dunia dan merupakan penyebab kematian utama. Pasien karsinoma payudara mengalami periode stres fisik dan emosional yang mendorong diproduksinya protein seperti interleukin-6 (IL-6). Interleukin-6 berperan penting dalam tumorigenesis karsinoma payudara melalui aktivasi jalur janus kinase (JAK). Penelitian ini mengukur kadar IL-6 serum yang berperan penting pada patogenesis molekuler proses metastasis pada karsinoma payudara lanjut lokal (KPLL) dibandingkan dengan karsinoma payudara bermetastasis (KPM). Rancangan penelitian adalah potong lintang, analitik komparatif dengan membandingkan kadar IL-6 serum rata-rata pada kedua kelompok KPLL dan KPM. Penelitian dilakukan di Rumah Sakit Dr. Hasan Sadikin Bandung (RSHS) dari Juni-November 2012. Subjek penelitian adalah 35 pasien yang terdiri atas 18 KPLL dan 17 KPM. Kadar IL-6 diukur dengan teknik pemeriksaan enzyme-linked immunosorbent assay (ELISA). Hasil yang diperoleh dari penelitian ini kadar IL-6 serum rata-rata pada KPLL 4,99 pg/mL dan kadar IL-6 serum pada KPM 32,73 pg/mL. Terdapat perbedaan bermakna kadar IL-6 serum antara KPLL dan KPM, p<0,01. Hasil analisis dengan uji chi-kuadrat pada derajat kepercayaan 95\%, bahwa terdapat hubungan kadar IL-6 serum dengan kejadian metastasis. Subjek dengan kadar IL-6 serum $>9,85$ pg/mL memiliki risiko kejadian metastasis 37,5 kali dibandingkan dengan kadar IL-6 serum $\leq 9,85$ pg/mL. Simpulan, kadar IL-6 serum pada KPM lebih tinggi dibandingkan dengan KPLL. [MKB. 2014;46(1):15-21]
\end{abstract}

Kata kunci: Interleukin-6, KPLL, KPM

\section{Serum Interleukin-6 Levels in Locally Advanced and Metastatic Breast Cancer}

\begin{abstract}
Breast carcinoma is a cancer in women with the highest frequency in the world and is the leading cause of death. Patients with breast carcinoma experience periods of stress both physical and emotional which encourages them to produce proteins such as interleukin-6 (IL-6). Interleukin-6 plays an important role in tumorigenesis via activation of janus activated kinase (JAK). This study measured the levels of serum IL-6 which plays an important role in the molecular pathogenesis of metastasis in locally advanced breast cancer (LABC) compared to metastatic breast cancer (MBC). The study design was cross-sectional, comparative analytics by comparing the mean levels of IL-6 in both groups: LABC and MBC. The study was conducted at the Dr. Hasan Sadikin Hospital Bandung (RSHS) from June-November 2012. Subjects were 35 women consisting of 18 LABC and 17 MBC. Levels of serum IL-6 were measured by enzyme-linked immunosorbent assay (ELISA) technique. The results of this study show that the mean levels of serum IL-6 on LABC $4.99 \mathrm{pg} / \mathrm{mL}$ and the mean levels of serum IL-6 on MBC $32.73 \mathrm{pg} / \mathrm{mL}$. There was a significant difference between the levels of serum IL- 6 on LABC and MBC, $p<0.01$. Results of the analysis with chi-square test shows there is a correlation between level of IL-6 with metastasis incidence. Subjects with levels of serum IL-6 $>9.85 \mathrm{pg} / \mathrm{mL}$ had 37,5 times higher risk for incidence of metastasis. In conclusion, the levels of serum IL-6 on MBCare higher than LABC. [MKB. 2014;46(1):15-21]
\end{abstract}

Key words: Interleukin-6, LABC, MBC

Korespondensi: Toha Sapari, dr., SMF Bedah Rumah Sakit Umum Daerah Tasikmalaya, Jalan Rumah Sakit No. 33 Tasikmalaya 46113, Tlp.0265-311139, mobile 08122195068,e-mail tohasapari@yahoo.co.id 


\section{Pendahuluan}

Karsinoma payudara adalah suatu kanker pada wanita dengan frekuensi tertinggi di dunia dan merupakan penyebab kematian utama di negara maju. ${ }^{1}$ Karsinoma payudara lanjut lokal (KPLL) di Amerika, merupakan 2-5\% dari seluruh kasus karsinoma pada payudara. ${ }^{2}$ Karsinoma payudara lanjut lokal mencakup grup heterogen tanpa metastasis yang jauh $\left(\mathrm{M}_{0}\right)$, termasuk kategori ini meliputi KPLL yang nonoperabel yaitu stadium klinis $\mathrm{T}_{3} \mathrm{~N}_{1} \mathrm{M}_{0}$ dan KPLL operabel yaitu stadium klinis $\mathrm{T}_{4}^{3}$ dan atau $\mathrm{N}_{2-3} \mathrm{M}_{0}{ }^{2}{ }^{2}$ Karsinoma payudara bermetastasis (KPM) adalah karsinoma payudara yang telah menyebar melalui jalur limfatik atau hematogen ke organ lain. Lokasi metastasis yang paling sering adalah tulang, paru-paru, hepar, dan otak. $^{2}$

Sistem imun yang didapat maupun bawaan memiliki peranan penting dalam respons, ${ }^{3}$ antitumor. Interaksi antara sistem imun inang dan sel tumor telah menjadi subjek penelitian beberapa dekade terakhir. ${ }^{3}$ Pada wanita karsinoma payudara, terdapat kegagalan yang bermakna dalam sistem kekebalan tubuh, yaitu respons imun yang lemah sehingga sel kanker payudara dikenali sangat buruk oleh sistem imun tubuh. ${ }^{4}$ Interleukin-6 (IL6) merupakan sitokin pleiotropik dengan aktivitas biologis yang luas dan memberikan beberapa efek terhadap sel kanker, ${ }^{5,6}$ di antaranya berperan penting dalam melawan proses apoptosis dan meningkatkan agresivitas tumor. ${ }^{7-9}$

Interleukin-6 (IL-6) yang berikatan dengan reseptornya mengaktivasi jalur janus activated kinase (JAK) dan melakukan fosforilasi signal transducers and activators of transcription (STAT). ${ }^{8}$ Signal transducers and activators of transcription mempunyai peranan dalam proses tumorigenesis kanker payudara. Hal ini berdasarkan penelitian didapatkan ekspresi STAT yang sangat tinggi pada sel kanker. Menghambat atau menghilangkan STAT akan meningkatkan apoptosis dan sensitivitas kemoterapi serta dapat menurunkan proses angiogenesis. ${ }^{9}$ Interleukin-6 menginduksi sintesis messenger ribo nucleic acid (mRNA) vascular endothelial growth factor (VEGF) dan mengaktivasi protein Rho sehingga berperan dalam angiogenesis dan adhesi sel pada keganasan. ${ }^{10}$ Beberapa peneliti juga menemukan bahwa reseptor estrogen menekan ekspresi IL-6 pada sel kanker payudara. ${ }^{11}$

Pada dekade terakhir ini, penatalaksanaan karsinoma payudara tersebut telah mengalami peningkatan yang pesat, namun $>30 \%$ karsinoma payudara meninggal dunia karena metastasisnya. ${ }^{12}$ Interleukin-6 sebagai sitokin yang berperan dalam patogenesis karsinoma payudara belum dapat dijadikan sebagai landasan dalam memprediksi metastasis oleh karena tidak terdapat kesamaan hasil di antara para peneliti mengenai nilai batas (cut-off point) dalam menentukan kemungkinan terjadinya metastasis. Penelitian ini dilakukan untuk mengukur kadar IL-6 serum yang berperan penting dalam patogenesis proses metastasis pasien KPLL dibandingkan dengan KPM, untuk menilai apakah kadar IL-6 serum dapat menjadi alternatif sebagai penanda progresivitas tumor.

\section{Metode}

Penelitian ini merupakan suatu penelitian potong lintang rancangan analitik komparatif dengan membandingkan kadar IL-6 serum rata-rata antara KPLL dan KPM. Subjek penelitian ini adalah penderita karsinoma payudara yang berobat di Rumah Sakit Dr. Hasan Sadikin (RSHS) Bandung dan didiagnosis secara klinis dan histopatologi sebagai KPLL dan KPM yang memenuhi kriteria inklusi dan tidak termasuk eksklusi serta bersedia mengikuti penelitian (informed consent). Kriteria eksklusi adalah penderita penyakit jantung, hati dan ginjal secara klinis atau laboratoris; riwayat menderita infeksi akut maupun kronik; riwayat menderita kanker payudara yang sudah diterapi maupun riwayat menderita kanker jenis lain. Dalam penelitian ini ukuran sampel ditentukan dengan mempergunakan formula uji hipotesis dua rata-rata, sehingga didapatkan besar sampel minimal kelompok KPLL dan KPM, masingmasing 16 subjek.

Karsinoma payudara diagnosisnya ditegakkan berdasarkan anamnesis, pemeriksaanklinis, diikuti biopsi insisi. Pemeriksaan penunjang dilakukan untuk menentukan stadium berupa foto polos dada posisi posteroanterior (PA), ultrasonografi (USG) hepar, serta sidik tulang. Pemeriksaan penapis metastasis ke otak dilakukan melalui pemeriksaan klinis dan anamnesis, yaitu ada tidaknya keluhan kenaikan tekanan intrakranial berupa muntah menyemprot dan atau nyeri kepala. Fungsi jantung normal adalah hasil pemeriksaan klinis dan penapis dengan cara rekam jantung/ elektrokardiografi (ECG) dalam batas normal. Fungsi hati normal adalah hasil pemeriksaan klinis dan penapis dengan pemeriksaan serum glutamic oxaloacetic transaminase (SGOT) dan serum glutamic pyruvic transaminase (SGPT) dalam batas normal. Fungsi ginjal normal adalah hasil pemeriksaan klinis dan penapis dengan pemeriksaan ureum dan kreatinin dalam batas normal.

Sampel darah vena diambil untuk pemeriksaan kadar IL-6 serum di Laboratorium Departemen Patologi Klinik Fakultas Kedokteran Universitas Padjadjaran/RSHS Bandung, Pemeriksaan IL-6 
serum mempergunakan teknik enzyme-linked immunosorbent assay (ELISA) dengan reagen katalog \#D6050/S6050. Volume darah vena $5 \mathrm{~mL}$ dimasukkan ke dalam kontainer darah (vacuette) dengan antikoagulan natrium sitrat 3,2\% atau ke dalam serum separator tube biarkan darah membeku dalam waktu 30 menit. Dilakukan sentrifus $3.000 \mathrm{rpm}$ selama 15 menit, kemudian cairan serum diambil dan disimpan dalam lemari pendingin dengan suhu $<-20{ }^{\circ} \mathrm{C}$ sampai jumlah sampel mencukupi untuk dilakukan pemeriksaan IL-6.

Data yang terkumpul diolah secara manual dan digital untuk mengubah data menjadi informasi. Analisis data berupa analisis univariabel bertujuan menggambarkan karakteritik subjek penelitian. Uji normalitas dilakukan dengan KolmogorovSmirnov. Dilakukan analisis bivariabel untuk membandingkan perbedaan kadar IL-6 antara KPLL dan KPM. Uji Mann Whitney digunakan apabila data tidak berdistribusi normal dan uji t-independen bila data berdistribusi normal. Bila variabel IL-6 dikategorikan berdasarkan kurva receiver operating characteristics (ROC) maka uji statistik yang digunakan adalah uji chi-kuadrat

Penelitian ini dilaksanakan Juni-November 2012 di Divisi Bedah Onkologi, Kepala/Leher, Departemen Ilmu Bedah Fakultas Kedokteran Universitas Padjadjaran/RSHS Bandung dan di Departemen Patologi Klinik Fakultas Kedokteran
Universitas Padjadjaran/RSHS Bandung.

Penelitian ini menggunakan objek penelitian yaitu darah vena penderita, sehingga penelitian ini dilaksanakan setelah memperoleh persetujuan Departemen Patologi Klinik Fakultas Kedokteran Universitas Padjadjaran (Unpad)/RSHS Bandung dan juga rekomendasi dari Komite Etik Penelitian Kesehatan Fakultas Kedokteran (FK) Universitas Padjadjaran/RSHS Bandung, nomor: LB.04.01/ A05/EC/007/II/2012.

\section{Hasil}

Usia rata-rata subjek penelitian adalah 48,5 tahun dengan rentang 32-70 tahun. Lebih dari setengah subjek penelitian berada dalam status menopause, 19 penderita. Status metastasis ke kelenjar getah bening (KGB) regional pada kedua kelompok relatif sama dengan status $\mathrm{N}_{0}$ dan $\mathrm{N}_{2}$ merupakan terbanyak ke-1 dan ke-2 dengan masing-masing berjumlah 18 dan 10 (Tabel 1).

Variabel yang dinilai hubungan dengan kadar Interleukin-6 (IL-6) serum, hanya gradasi yang mempunyai keeratan hubungan secara signifikan. Variabel usia, status menopause, dan metastasis ke KGB regional tidak mempunyai hubungan secara signifikan dengan kadar IL-6 serum.

Sebelum dilakukan analisis statistik untuk jenis data numerik kadar IL-6 serum, dilakukan

Tabel 1 Hubungan Karakteristik Subjek Penelitian dengan Kadar IL-6 Serum

\begin{tabular}{lccccc}
\hline \multicolumn{1}{c}{ Variabel } & $\begin{array}{c}\text { KPLL } \\
(\mathbf{n}=\mathbf{1 8})\end{array}$ & $\begin{array}{c}\text { KPM } \\
\mathbf{( n = 1 7 )}\end{array}$ & $\begin{array}{c}\text { Total } \\
(\mathbf{n}=\mathbf{3 5})\end{array}$ & $\mathbf{r s * )}$ & $\mathbf{p}$ \\
\hline Usia & & & & & \\
Rata-rata & 47,7 & 51,2 & 48,5 & & \\
Median (rentang) & $49(32-70)$ & $50(35-66)$ & $49(32-70)$ & & \\
Status menopause & & & & 0,000 & $>0,05$ \\
Menopause & 9 & 10 & 19 & & \\
Nonmenopause & 9 & 7 & 16 & & 0,991 \\
Metastasis KGB & & & & 0,002 & \\
$\quad$ N0 & 9 & 9 & 18 & & \\
$\quad$ N1 & 1 & 1 & 2 & & \\
$\quad$ N2 & 5 & 5 & 10 & & \\
$\quad$ N3 & 3 & 2 & 5 & & \\
Gradasi & & 3 & 19 & & \\
$\quad$ I & 16 & 8 & 10 & & \\
II & 2 & 6 & 6 & & \\
$\quad$ III & 0 & 3 & & & \\
\hline
\end{tabular}

Keterangan: *) rs: koefisien korelasi Rank Spearman; KGB=kelenjar getah bening 
Tabel 2 Distribusi Data Kadar IL-6 Serum pada KPLL dan KPM*)

\begin{tabular}{llcc}
\hline $\begin{array}{l}\text { Kadar IL-6 } \\
\text { Serum }\end{array}$ & $\mathbf{n}$ & $\mathbf{Z}$ & $\mathbf{p}$ \\
\hline KPLL & 18 & 1,109 & 0,170 \\
KPM & 17 & 0,868 & 0,438 \\
\hline
\end{tabular}

*) one-sample Kolmogorov-Smirnov test

uji normalitas distribusi data pada kedua variabel. Uji statistik pada kedua variabel menggunakan Uji normalitas Kolmogorov-Smirnov (Tabel 2).

Nilai statistik Kolmogorov-Smirnov Z untuk kadar interleukin-6 serum pada KPLL=1,109 dengan peluang kesalahan $\mathrm{p}=0,170$. Nilai statistik untuk kadar IL-6 serum pada KPM $=0,868$ dengan peluang kesalahan $p=0,438$. Nilai $p>\alpha=0,05$; berarti nonsignifikan. Kedua variabel mempunyai distribusi normal pada taraf kesalahan 5\%. Variasi kadar IL-6 serum pada KPLL (93\%) lebih tinggi daripada variasi kadar IL-6 serum pada KPM $(87,5 \%)$. Dengan menggunakan Uji F-Levene dalam uji t-independen didapatkan nilai $\mathrm{p}=0,001$ ( $<<0,05$; signifikan). Variasi kedua variabel tidak sama (berbeda) pada taraf kesalahan 5\%. Dengan kata lain, kedua variabel bersifat heterogen (Tabel $3)$.

Kadar IL-6 serum rata-rata pada KPM $(32,73$ $\mathrm{pg} / \mathrm{mL})$ lebih tinggi daripada KPLL (4,99 pg/ $\mathrm{mL}$ ). Kadar IL-6 serum rata-rata pada KPM berbeda secara signifikan $(p<0,01)$ dengan kadar IL-6 serum rata-rata pada KPLL dengan tingkat kepercayaan 95\% (Gambar 1).

Berdasarkan hasil analisis kurva ROC dalam perbedaan antara kadar IL-6 serum KPLL dan KPM diperoleh nilai cut-off kadar IL- $6=9,85 \mathrm{pg} /$ $\mathrm{mL}$ yang membentuk kelas $\leq 9,85 \mathrm{pg} / \mathrm{mL}$ dan $>9,85 \mathrm{pg} / \mathrm{mL}$. Sensitivitas kadar IL-6 serum terhadap kejadian metastasis sebesar 88,2\% dan spesifisitasnya terhadap kejadian metastasis $83,3 \%$. Nilai sensitivitas serta spesifisitas ini sesuai dengan nilai sensitivitas dan spesifisitas hasil analisis kurva ROC (Gambar 2).

Hasil analisis dengan uji chi-kuadrat pada derajat kepercayaan yaitu $95 \%$, terdapat hubungan antara kadar IL-6 serum dan kejadian metastasis $(\mathrm{p}<0,01)$. Prediksi nilai positif pada hasil yang positif berdasarkan kadar IL-6 serum terhadap kejadian metastasis adalah $83,3 \%$, sedangkan prediksi nilai negatif kadar IL-6 serum terhadap kejadian metastasis sebesar $88,2 \%$ dengan nilai akurasi 85,7\% (Tabel 4).

Tabel 3 Homogenitas Kadar IL-6 Serum antara KPLL dan KPM

\begin{tabular}{lccccc}
\hline $\begin{array}{c}\text { Kadar } \\
\text { IL-6 Serum }\end{array}$ & $\mathbf{n}$ & $\begin{array}{c}\text { Rata-rata } \\
(\mathbf{p g} / \mathbf{m L})\end{array}$ & SB & $\begin{array}{c}\text { Koefisien } \\
\text { Variasi }\end{array}$ & $\left.\mathbf{p}^{*}\right)$ \\
\hline & & & & & $<0,01$ \\
KPLL & 18 & 4,99 & 4,645 & $93,0 \%$ & \\
KPM & 18 & 32,73 & 28,648 & $87,5 \%$ & \\
\hline
\end{tabular}

Keterangan: *) Uji F-Lavene dalam uji t-independent; $\mathrm{SB}=$ simpangan baku

\section{Pembahasan}

Usia termuda subjek penelitian pada kelompok KPLL adalah 32 tahun dan pada kelompok KPM 35 tahun, sedangkan usia tertua pada kelompok KPLL adalah 70 tahun dan pada KPM 65 tahun. Usia rata-rata pada kedua kelompok adalah 48,5 tahun. Hasil penelitian ini mendapatkan usia rata- rata penderita karsinoma payudara mengalami pergeseran menjadi lebih muda, yaitu berada di bawah usia 50 tahun. Walaupun karsinoma payudara dapat menyerang pada usia berapapun, pergeseran usia ini dapat disebabkan karena beberapa faktor, di antaranya perubahan gaya hidup seperti mengonsumsi minuman beralkohol dan obesitas. ${ }^{13}$ Terdapat beberapa faktor yang

Tabel 4 Hubungan Kadar IL-6 Serum dengan Kejadian Metastasis

\begin{tabular}{cccccc}
\hline $\begin{array}{l}\text { Kadar IL-6 } \\
\text { Serum }\end{array}$ & $\begin{array}{c}\text { KPLL } \\
(\mathbf{n = 1 8})\end{array}$ & $\begin{array}{c}\text { KPM } \\
(\mathbf{n = 1 7})\end{array}$ & $\left.\mathbf{p}^{*}\right)$ & OR & $\mathbf{9 5 \%}$ IK \\
\hline & & & $<0,01$ & 37,5 & $5,46-257,6$ \\
$>9,85(\mathrm{pg} / \mathrm{mL})$ & 3 & 15 & & \\
$\leq 9,85(\mathrm{pg} / \mathrm{mL})$ & 15 & 2 & & \\
\hline
\end{tabular}

Keterangan: *) uji chi-kuadrat; $\mathrm{OR}=$ odds ratio; $\mathrm{IK}=$ interval kepercayaan 


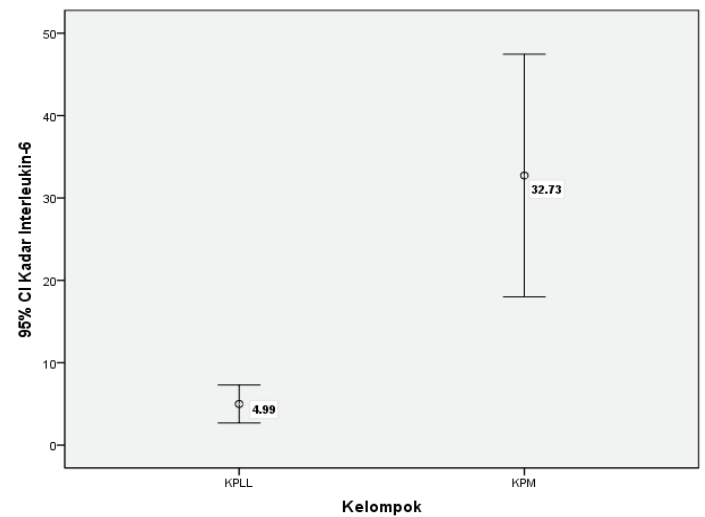

Gambar 1 Interval Kadar IL-6 Serum Ratarata pada KPLL dan KPM

menempatkan wanita muda pada risiko tinggi menderita karsinoma payudara, yaitu riwayat karsinoma atau nonkarsinoma pada payudara, riwayat keluarga dengan karsinoma payudara terutama pada ibu, anak perempuan atau saudara perempuan, riwayat terapi radiasi pada dada sebelum usia 40 tahun, dan terbukti mempunyai kelainan genetik (mutasi BRCA1/BRCA2). ${ }^{13}$

Variabel gradasi tersebut mempunyai keeratan hubungan yang sangat tinggi dengan IL-6 serum; $0,80 \leq \mathrm{r}_{\mathrm{s}}<1,000$. Koefisien korelasi keduanya bernilai positif yang memperlihatkan hubungan antara keduanya searah. Terdapat kecenderungan yang sangat kuat dan signifikan bahwa semakin tinggi gradasi, semakin tinggi kadar IL-6. Kadar IL-6 meningkat bersamaan dengan peningkatan gradasi tumor dan tumor payudara menghasilkan lebih banyak IL-6 dibandingkan dengan kelenjar payudara yang normal. ${ }^{14}$ Peningkatan kadar IL-6 juga berhubungan dengan karsinoma payudara stadium lanjut yang mempunyai gradasi tinggi. ${ }^{15}$

Variabel usia, status menopause, dan metastasis KGB tidak berhubungan secara signifikan dengan kadar IL-6 serum. Secara deskriptif, keeratan hubungan antara usia, status menopause, dan juga status metastasis KGB tergolong sangat rendah, yaitu $0,00 \leq \mathrm{r}_{\mathrm{s}}<0,199$. Tidak ada kecenderungan yang signifikan bahwa semakin tinggi usia dan metastasis KGB, semakin tinggi pula kadar IL-6 serum. Sama halnya dengan status menopause bahwa tidak ada kecenderungan yang signifikan bahwa kadar IL-6 dalam serum pada menopause lebih tinggi daripada nonmenopause ataupun sebaliknya.

Dengan menggunakan uji statistik diketahui bahwa data kedua variabel berdistribusi normal dan bersifat heterogen sehingga data dianalisis menggunakan uji parametrik t-independen untuk membedakan rata-rata pada kedua kelompok

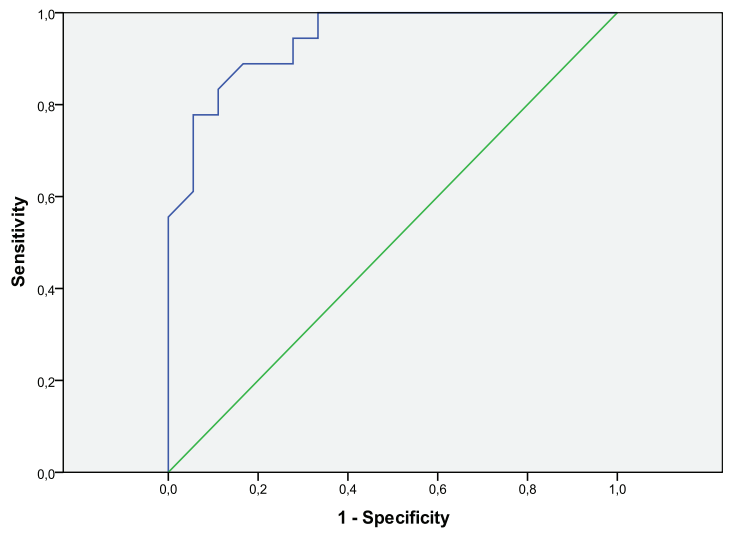

Gambar 2 Kurva Receiver Operating
Characteristic (ROC)

yang kemudian dibandingkan dengan uji koreksi kontinuitas untuk melihat korelasi dua variabel.

Kadar IL-6 serum rata-rata pada KPM lebih tinggi dibandingkan dengan KPLL, yaitu $32,73 \mathrm{pg} /$ $\mathrm{mL}$ dan $4,99 \mathrm{pg} / \mathrm{mL}$. Hasil analisis ujit-independen pada taraf kesalahan $5 \%$ menunjukkan perbedaan signifikan $(p<0,01)$ antara kadar IL-6 serum pada KPLL dan KPM. Kozlowski dkk. ${ }^{15}$ dalam penelitiannya mendapatkan hasil kadar IL-6 serum pada penderita karsinoma payudara lebih tinggi dibandingkan dengan kelompok kontrol dengan rata-rata $31,7 \mathrm{pg} / \mathrm{mL}$. Ravishankaran dan Karunanuthi ${ }^{10}$ menemukan bahwa kadar IL-6 serum lebih tinggi pada KPM $(39,7 \pm 9,3 \mathrm{pg} /$ $\mathrm{mL}$ ) dibandingkan dengan penderita yang belum mengalami metastasis jauh $(17,3 \pm 7,6 \mathrm{pg} / \mathrm{mL})$.

Kadar IL-6 rata-rata KPLL yang didapatkan pada penelitian Kozlowski dkk. ${ }^{15}$ Ravishankaran dan Karunanuthi ${ }^{8}$ lebih tinggi bila dibandingkan dengan hasil yang didapatkan pada penelitian ini, yaitu $>40 \mathrm{pg} / \mathrm{mL}$. Perbedaan kadar IL-6 serum ratarata yang didapatkan oleh dua peneliti tersebut dengan penelitian ini karena perbedaan kriteria inklusi dan eksklusi yang diterapkan terhadap subjek penelitian. Kadar IL-6 dipengaruhi oleh banyak faktor seperti penyakit yang menyertai dan inflamasi.

Kadar IL-6 serum yang tinggi berkaitan dengan proses patologis yang terjadi pada kelompok KPM. Interleukin-6 yang disekresikan oleh sel karsinoma payudara telah terbukti berkontribusi dalam proses yang disebut "penyemaian sendiri (self-seeding)," sel tumor beredar secara agresif dalam lingkungan tumor mereka sendiri. ${ }^{16}$ Bukti yang kuat menunjukkan bahwa IL-6 mendorong pertumbuhan sel-sel kanker payudara dengan mengaktifkan STAT3 yang puncaknya mengatur proliferasi onkogen seperti c-Myc dan cyclin $\mathrm{D}_{1}$ serta faktor pertumbuhan seperti hepatocyte 
growth factor (HGF), VEGF, dan juga epidermal growth factor (EGF). ${ }^{17}$

Dari penelitian ini diperoleh nilai batas (cutoff point) kadar IL-6 serum pada KPLL dan KPM berdasarkan kurva ROC. Nilai batas kadar IL-6 serum untuk mendeteksi kemungkinan terjadi metastasis adalah $>9,85 \mathrm{pg} / \mathrm{mL}$. Pada penelitian lain yang dilakukan oleh Ravishankaran dan Karunanuthi ${ }^{8}$ dilaporkan nilai batas kadar IL-6 serum pada karsinoma payudara belum metastasis dengan yang sudah bermetastasis adalah 20,3 pg/ $\mathrm{mL}$.

Terdapat 2 subjek pada kelompok KPM yang memiliki nilai kadar IL-6 serum di bawah nilai batas, yaitu $6,9 \mathrm{pg} / \mathrm{mL}$ dan $8,1 \mathrm{pg} / \mathrm{mL}$. Begitu pun sebaliknya, ada 3 subjek pada kelompok KPLL memiliki nilai kadar IL-6 serum di atas nilai batas, yaitu 9,9 pg/mL, $12 \mathrm{pg} / \mathrm{mL}$, dan 15,9 pg/ $\mathrm{mL}$ (Tabel 4).

Ketidaksesuaian kadar IL-6 serum pada tiap kelompok penelitian ini sangat dimungkinkan oleh karena pada penelitian ini tidak memeriksa kadar protein fase akut yang lain, sehingga tidak dapat mengenyampingkan bahwa kadar IL-6 merupakan satu-satunya faktor yang berkaitan dengan proses patofisiologi karsinoma payudara. Fenomena yang sama dapat terjadi pada pasien karsinoma payudara yang bermetastasis. Secara statistik hal tersebut juga dimungkinkan karena sensitivitas dan spesifisitas kadar IL-6 serum terhadap kejadian metastasis tidak $100 \%$.

Berdasarkan analisis kurva ROC, sensitivitas kadar IL-6 serum terhadap kejadian metastasis adalah $88,2 \%$, artinya proporsi metastasis dapat diidentifikasikan positif berdasarkan kadar IL-6 serum sebesar 88,2\%. Spesifisitas kadar IL-6 serum terhadap kejadian metastasis adalah $83,3 \%$, artinya proporsi metastasis dapat diidentifikasikan negatif berdasarkan kadar IL-6 serum sebesar 83,3\% Dari hasil tersebut dapat terlihat bahwa kadar IL-6 serum mempunyai sensitivitas dan spesifisitas yang tinggi (di atas $80 \%$ ), sehingga kadar IL-6 serum dapat digunakan untuk tujuan membantu penegakan diagnosis maupun skrining pasien karsinoma payudara bermetastasis.

Prediksi nilai positif pada hasil yang positif menurut kadar IL-6 serum terhadap kejadian metastasis sebesar $83,3 \%$, sedangkan prediksi nilai negatif dari kadar IL-6 serum terhadap kejadian metastasis adalah sebesar $88,2 \%$ dengan nilai akurasi $85,7 \%$. Hasil analisis dengan uji chikuadrat pada derajat kepercayaan $95 \%$, terdapat hubungan yang bermakna antara kadar IL-6 serum dan kejadian metastasis dengan $p<0,01$.

Analisis keeratan menunjukkan bahwa tingkat keeratan hubungan antara kadar IL-6 serum dan status karsinoma payudara tergolong tinggi. Kadar IL-6 serum $>9,85 \mathrm{pg} / \mathrm{mL}$ memiliki risiko kejadian metastasis 37,5 kali dibandingkan dengan kadar IL-6 serum $\leq 9,85 \mathrm{pg} / \mathrm{mL}$. Simpulan, kadar IL-6 serum pada wanita dengan KPM lebih tinggi dibandingkan dengan KPLL dengan nilai batas $9,85 \mathrm{pg} / \mathrm{mL}$.

\section{Daftar Pustaka}

1. Jemal A, Siegel R, Ward E, Hao Y, Xu J, Thun MJ. Cancer statistics 2009. CA Cancer J Clin. 2009;59(4):225-49.

2. Conzen SD, Grushko TA, Olopade OI. Cancer principles \& practice oncology. Dalam: DeVita VT, Lawrence TS, Rosenberg SA, penyunting. Cancer of the breast. Edisi ke-8. Philadelphia: Lippincot Williams \& Wilkins; 2008. hlm. 1595-654.

3. Knupfer H, Preis R. Significance of interleukin-6 (IL-6) in breast cancer (review). Breast Cancer Res Treat. 2007;102(2):12935.

4. Allan CP, Turtle CJ, Mainwaring PN, Pyke C, Hart DN. The immune response to breast cancer, and the case for DC immunotherapy. Cytotherapy. 2004;6(2):154-63.

5. Kishimoto T. Interleukin-6: discovery of pleiotropic cytokine. Arthritis Res Ther. 2006;8 Suppl 2:S2.

6. Thong-Ngam D, Tangkijvanich P, Lerknimitr R, Mahachai V, Theamboonlers A, Poovorawan Y. Diagnostic role of serum interleukin-18 in gastric cancer patiens. World J Gastroenterol. 2006;12(28):4473-7.

7. Leu CM, Wong FH, Chang C, Huang SF, Hu CP. Interleukin-6 acts as an antiapoptotic factor in human esophageal carcinoma cells through the activation of both STAT3 and mitogen-activatied protein kinase pathways. Oncogene. 2003;22(49):809-18.

8. Ravishankaran P, Karunanithi R. Clinical significance of preoperative serum interleukin-6 and C-reactive protein level in breast cancer patients. World J Surg Oncol. 2011;9:18.

9. Gritsko T, Williams A, Turkson J, Kaneko S, Bowman T, Huang M, dkk. Persistent activation of stat 3 signaling induces survivin gene expression and confers resistance to apoptosis in human breast cancer cells. Clin Cancer Res. 2006;12(1):11-9.

10. Lin MT, Lin BR, Chang CC, Chu CY, Su HJ, Chen ST, dkk. IL-6 induces AGS gastric cancer cell invasion via activation of the c-Src/RhoA/ROCK signaling pathway. Int J Cancer. 2007;120(12):2600-8.

11. Bhat-Nakshatri P, Campbell RA, Patel NM, Newton TR, King AJ, Marshall MS, dkk. 
Tumour necrosis factor and P13-kinase control oestrogen receptor alpha protein level and its transrepression function. Br J Cancer. 2004;90(4):853-9.

12. Han Y, Liu L, Yan D, Wang G. Correlation between expression of P38 MAPK-signaling and uPA in breast cancer. Clin Oncol Cancer Res. 2008;5:161-4.

13. Breast Cancer Health Center. Breast cancer in young women [diunduh 8 Maret 2013]. Tersedia dari: http://www.webmd.com/ breast-cancer/guide/breast-cancer-youngwomen.

14. Sullivan NJ. Breast cancer: focusing tumor microenvironment, stem cells and metastasis. Dalam: Mehmet G, Esra G, penyunting. Interleukin- 6 in the breast tumor microenvironment. Edisi ke-2. Rijeka, Croatia: In Tech; 2011. hlm. 165-82.

15. Kozlowski L, Zakrzewska I, Tokajuk P, Wojtukiewicz MZ. Concentration of interleukin-6 (IL-6), interleukin-8 (IL-8) and interleukin-10 (IL-10) in blood serum of breast cancer patients. Rocz Akad Med Bialymst. 2003;48:82-4.

16. Kim MY, Oskarsson T, Acharyya S, Nguyen DX, Zhang XH, Norton L, dkk. Tumor selfseeding by circulating cancer cells. Cell. 2009;139:1315-26.

17. Yu H, Pardoll D, Jove R. STATs in cancer inflammation and immunity: a leading role for STAT3. Nat Rev Cancer. 2009;9(11):798809. 